\title{
Evaluasi Karakteristik Antibakteri Ekstrak Heksan Kulit Batang Drimys piperita Hook f. terhadap Pertumbuhan Bakteri Patogenik dalam Medium Padat Evaluation of Hexane Extracts of Drimys piperita Hookf. Stem Barks on Growth of Patogenic Bacteria on Solid Medium
}

\author{
Gino Nemesio Cepeda ${ }^{a^{*}}$, Meike Meilan Lisangana, Isak Silambaa, Nitia Nilawatib \\ dan Eka Syartikab
}

aJurusan Teknologi Pertanian, Fakultas Teknologi Pertanian, Universitas Papua, Manokwari, Indonesia

${ }^{b}$ Alumni Jurusan Teknologi Pertanian, Fakultas Teknologi Pertanian, Universitas Papua, Manokwari, Indonesia

\section{Riwayat Naskah:}

Diterima Februari 2020 Direvisi November 2020 Disetujui November 2020

\begin{abstract}
ABSTRAK: Drimys piperita Hook f. adalah salah satu jenis tumbuhan aromatik yang dikelompokkan dalam keluarga Winteraceae. Tumbuhan ini merupakan tumbuhan obat tradisional Suku Sougb yang bermukim di Pengunungan Arfak Papua Barat untuk pengobatan malaria dan peningkatan vitalitas tubuh. Penelitiaan ini bertujuan untuk mengetahui kemampuan antibakteri ekstrak heksan kulit batang akway dan stabilitas antibakterinya terhadap pengaruh tingkat keasaman $(\mathrm{pH})$, pemanasan dan konsentrasi natrium klorida secara in vitro serta potensinya sebagai pengawet pangan. Ekstraksi komponen antibakteri dilakukan menggunakan metode perendaman (maserasi) dalam pelarut heksan (maserasi) selama 72 jam. Pengujian aktivitas antibakteri dilakukan menggunakan metode agar well diffusion pada empat bakteri uji, yaitu Escherichia coli, Pseudomonas aeruginosa, Bacillus cereus dan Staphylococcus aureus. Hasil riset memperlihatkan bahwa ekstrak heksan kulit batang akway bersifat menghambat pertumbuhan $S$. aureus, E. coli, dan B. cereus dengan konsentrasi terendah 0,35-0,89\%. Esktrak tahan terhadap pemanasan $100^{\circ} \mathrm{C}$ dalam waktu 25 menit dan konsentrasi natrium klorida $\leq 5 \%$. Perlakuan $\mathrm{pH} 4$ dan $\mathrm{pH}$ 8,5 dapat meningkatkan aktivitas antibakteri ekstrak. Ekstrak berpotensi sebagai pengawet pangan yang diproses dengan pemanasan dan pengasaman.
\end{abstract}

Kata kunci: antibakteri, ekstrak heksan, kulit batang Drimys piperita

ABSTRACT: Drimys piperita Hook f. is an aromatic plant that was included in family of Winteraceae. This plant is a traditional medical plant of Sougb tribe who leaved in Arfak Mountains, West Papua for healing malaria and enhancing vitality. The aims of the study were to evaluate in vitro antibacterial capacities of its barks hexane extracts and antibacterial stability of extracts on different $\mathrm{pH}$, heating and natrium chloride concentrations also its potency as food preservative. Hexane extraction of barks powder was performed using Soaking method (maceration) for 72 hours. Antibacterial activity assays of extracts were done using method of agar well diffusion on four tested bacteria including Escherichia coli, Pseudomonas aeruginosa, Bacillus cereus and Staphylococcus aureus. The result indicated that hexane extracts inhibited growth of S. aureus, E. coli, and B. cereus at minimum concentration of $0.35-0.89 \%$. Extract was resisten on heating temperature of $100^{\circ} \mathrm{C}$ for 25 minutes and natrium chloride concentration up to $5 \%$. The Treatment of $\mathrm{pH} 4$ and $\mathrm{pH} 8.5$ increased antibacterial activity of extracts. The extract has potency used as preservative agent for food produced by heating and acidifying process.

\footnotetext{
Kontributor utama

Email : ginocepeda.gc@gmail.com
} 


\section{Pendahuluan}

Pertumbuhan bakteri dalam pangan yang berdampak pada mutu dan keamanan pangan menjadi perhatian utama bagi konsumen, industri pangan dan lembaga penjamin keamanan pangan (Campelo, Medeiros, \& Silva, 2019). Bakteri memanfaatkan komponen gizi dalam pangan yang mengakibatkan perubahan flavour, bau, warna, sensori, tekstur dan kerusakan pangan, disamping itu juga dapat menyebabkan penyakit melalui pangan yang disebabkan oleh bakteri patogen yang mengkontaminasi pangan (Mahmud dan Khan, 2018). Kebanyakan bakteri yang mengkontaminasi dan menyebabkan kerusakan pangan serta menyebabkan penyakit adalah bakteri $P$. aeruginosa, E. coli, S. aureus, Bacillus cereus dan Salmonella typhi (Mostafa et al., 2018).

Pengunaan pengawet sintetik yang bersifat antibakteri untuk menghambat pertumbuhan bakteri yang menyebabkan kerusakan pangan serta bersifat patogen telah lama dilakukan oleh industriindusti pangan. Oleh karena persepsi konsumen bahwa konsumsi pengawet sintetik yang berlebihan berdampak pada perkembangan penyakit degeneratif sehingga memicu berkembangnya penelitian untuk mendapatkan pengawet alami dan bersifat antibakteri yang bersumber dari tumbuhan (Krishnan et al., 2014).

Drimys piperita adalah tumbuhan aromatik yang yang dikelompokkan ke dalam keluarga winteraceae (Stevens, 2017). Tumbuhan ini dikenal dengan nama"akway" dan dimanfaatkan sebagai obat herbal tradisional oleh Suku Sougb yang bermukim di Pengunungan Arfak Papua Barat untuk pengobatan penyakit malaria dan untuk peningkatkan vitalitas tubuh (Syakir, Bermawie, Agusta, \& Paysei, 2011). Kandungan senyawa aromatik dalam bagian daun tumbuhan ini sebesar $0,2 \%(\mathrm{v} / \mathrm{b})$, sedangkan dalam kulit batangnya mencapai $0,37 \%(\mathrm{v} / \mathrm{b})$ (Cepeda, Santoso, Lisangan, \& Silamba, 2011a; Cepeda, Santoso, Lisangan, \& Silamba, 2011b).

Beberapa kajian komponen bioaktif penyusun ekstrak kulit batang tumbuhan ini telah dilaporkan. Ekstrak heksan dilaporkan mengandung kelompok senyawa flavonoid, saponin, terpenoid, glikosida dan alkaloid (Cepeda, Santoso, Lisangan, \& Silamba, 2010) dan juga bagian kulit batangnya mengandung senyawa aromatik yang tersusun dari 4-terpineol $13,16 \%$, $\quad \beta$-pinen $14,88 \%$ dan $\alpha$-pinen $20,24 \%$ sebagai senyawa dengan kandungan terbesar (Cepeda et al., 2011b). Ekstrak etilasetat kulit batang akway mengandung senyawa fenolik 22,21 mg EAG/g (Cepeda, Lisangan, \& Roreng, 2018). Kelompok fenolik dan senyawa $\alpha$-pinen serta $\beta$ pinen yang terdapat dalam kulit batang akway dilaporkan bersifat antibakteri (Cushnie \& Lamb, 2005; Da Silva et al., 2012; Wang, Li, Luo, Zu, \&
Efferth, 2012).

Aktivitas antibakteri ekstrak tumbuhan bergantung pada beberapa faktor diantaranya jenis bakteri, jumlah sel bakteri, konsentrasi, tingkat keasaman $(\mathrm{pH})$, suhu dan kandungan sodium klorida (Seow, Yeo, Chung, \& Yuk, 2014). Ekstrak tumbuhan yang berpotensi sebagai pengawet pangan harus stabil terhadap perlakuan-pelakuan dalam proses pengolahan pangan seperti pemanasan, pengasaman dan penambahan garam sodium klorida. Tujuan penelitian ini adalah mengevaluasi karakteristik antibakteri ekstrak heksan yang diperoleh dari kulit batang akway terhadap bakteri patogen dalam pangan pada berbagai konsentrasi, tingkat keasaman $(\mathrm{pH})$, pemanasan pada suhu $100^{\circ} \mathrm{C}$ dan konsentrasi sodium klorida dan potensi ekstrak kulit batang akway sebagai sumber antibakteri alami untuk pengawetan pangan.

\section{Bahan dan Metode}

\subsection{Bahan}

Bahan-bahan yang digunakan meliputi kulit batang akway yang dikumpulkan dari desa Sururey Kecamatan Anggi, Kabupaten Pegunungan Arfak Provinsi Papua Barat dan bahan-bahan kimia yang terdiri dari $\mathrm{NaOH}, \mathrm{HCl}$, tween 20, natrium klorida yang diperoleh dari Merck Jerman, hexane yang diperoleh dari JT Baker USA, nutrient broth (NB) dan nutrient agar (NA) yang diperoleh dari Oxoid, tween 20, $\mathrm{NaOH}$ dan $\mathrm{HCl}$ dari Merck dan bakteri E. coli galur ATCC25922 (EC), $P$. aeruginosa galur ATCC27853 (PA), B. cereus galur ATCC10876 (BC) dan Staphylococcus aureus galur ATCC25923 (SA) dibeli dari Laboratorium Mikrobiologi PAU IPB.

\subsection{Alat}

Alat-alat penunjang penelitian meliputi moisture meter tipe T-S7 produksi Jepang, grinder Miyako Indonesia, saringan 40 mesh produksi ASTM USA, shaker incubator Lab-line ORBIT, pompa vakum, Eyela rotary evaporator N1000, kertas saring whatman no. 1, timbangan WAS 220/C/2 RADWAG, mikropipet eppendorf, tips, My life autoclave tipe MA678 Indonesia, Gerhardt hot plate Jerman, Labnusantara laminar air flow Indonesia, vortex, Niigata Seiki caliper produksi Jepang dan peralatan gelas.

\subsection{Metode}

Metode eksperimen adalah metode yang diterapkan dalam penelitian ini, sedangkan rancangan yang digunakan adalah rancangan acak kelompok dengan perlakuan konsentrasi ekstrak (0$25 \%)$, lama pemanasan ekstrak pada suhu $100^{\circ} \mathrm{C}(0-$ 
Sitasi: Cepeda, G. N., Lisangan, M. M., Silamba, S., Nilawati, N., \& Syartika, E (2020) Evaluasi karakteristik antibakteri ekstrak heksan kulit batang Drimys piperita Hook f. terhadap pertumbuhan bakteri patogenik dalam medium padat. Warta IHP, 37(2), 144-151

Halaman | 146

25 menit), variasi $\mathrm{pH}$ 4-8,5 serta konsentrasi natrum klorida ekstrak (0-5\%). Tiap-tiap perlakuan diuji pada 4 kelompok bakteri uji dengan replikasi sebanyak 3 kali. Pelaksanaan tahapan penelitian dilakukan di Laboratorium Mikrobiologi Fateta Universitas Papua.

\subsubsection{Persiapan bubuk kulit batang akway}

Kulit yang berasal dari batang utama dengan diameter \pm 8-10 $\mathrm{cm}$, dikeringkan-anginkan selama kurang lebih 5 - 7 hari hingga kandungan air mencapai $\pm 12 \%$. Kulit batang kering selanjutnya dipotong-potong dengan ukuran panjang 3-4 cm kemudian dibuat bubuk dengan grinder lalu diayak. Bubuk dikumpulkan lalu dikemas menggunakan wadah plastik tertutup.

\subsubsection{Proses ekstraksi bubuk kulit batang akway}

Sebanyak $200 \mathrm{~g}$ bubuk dimasukkan ke dalam Erlenmeyer 2 liter lalu ditambahkan pelarut hexan $800 \mathrm{ml}$. Campuran selanjutnya dimasukkan dalam shaker incubator. Proses ekstraksi dilakukan pada suhu ruang selama 72 jam. Setelah proses maserasi selesai, dilakukan penyaringan dengan pompa vakum. Filtrat yang tertampung diuapkan dalam rotary evaporator dengan kecepatan putar $60 \mathrm{rpm}$ pada suhu $40^{\circ} \mathrm{C}$. Ekstrak yang diperoleh dilanjutkan dengan penguapan sisa pelarut di dalam refrigerator. Ekstrak yang diperoleh dimasukkan dalam botol dan disimpan dalam refrigerator untuk digunakan dalam pengujian.

\subsubsection{Persiapan kultur bakteri uji}

Vial isolat kultur bakteri ditambahkan $1 \mathrm{ml}$ NB lalu diaduk dengan vorteks. Campuran kultur dipipet lalu dimasukkan ke dalam tabung reaksi yang telah berisi NB $10 \mathrm{ml}$. Kultur dimasukkan dalam incubator suhu $37^{\circ} \mathrm{C}$ selama 24 jam. Kultur selanjutnya dipindahkan pada permukaan agar miring lalu dimasukkan dalam inkubator suhu $37^{\circ} \mathrm{C}$ dengan waktu inkubasi 24 jam. Setelah waktu inkubasi selesai kultur yang tumbuh digunakan dalam pengujian.

Sebanyak 1 ose kultur bakteri dari media NA dipindahkan dalam $10 \mathrm{ml}$ NB kemudian diaduk menggunakan vortex dan diinkubasi selama 24 jam. Setelah waktu inkubasi selesai jumlah sel bakteri dihitung menggunakan pengenceran seri menggunakan metode pour plate pada medium NA. Jumlah sel bakteri pada perhitungan tersebut menjadi dasar untuk melakukan pengenceran seri kultur bakteri menjadi $10^{7} \mathrm{CFU} / \mathrm{ml}$ bakteri pada setiap pengujian.

\subsubsection{Pengujian antibakteri pada beberapa tingkat konsentrasi ekstrak}

Evaluasi antibakteri ekstrak dilakukan menggunakan metode difusi pada medium agar (Balouiri, Sadiki, \& Ibnsouda, 2016). Kultur uji sejumlah 0,5 ml dengan jumlah sel $10^{7} \mathrm{CFU} / \mathrm{ml}$ disebarkan di permukaan medium NA pada cawan petri selanjutnya dibuat sumur dengan ukuran diameter $6 \mathrm{~mm}$ pada medium NA menggunakan tips. Ke dalam tiap-tiap sumur dimasukkan $60 \mu \mathrm{l}$ ekstrak berdasarkan variasi konsentrasi, yaitu 0\% (pelarut), 5\%, 10\%, 15\%, 20\%, 25\% (b/v). Sebagai kontrol positif digunakan $10 \%$ penicillin G. Masing-masing cawan diinkubasi dalam inkubator suhu $37^{\circ} \mathrm{C}$ dalam waktu 24 jam. Diameter penghambatan (zona jernih di sekeliling sumur) diukur dengan kaliper.

\subsubsection{Penentuan konsentrasi hambat minimum (KHM)}

Penentuan KHM menggunakan metode regresi linear (Bloomfield, 1991). Regresi linear dibuat antara ln konsentrasi (sumbu X) dan kuadrat penghambatan ekstrak (sumbu Y). Persamaan regresi linear $\mathrm{Y}=\mathrm{bX}+\mathrm{a}$ yang berpotongan pada sumbu X, adalah titik Kx (nilai ln konsentrasi). Nilai KHM adalah 25\% x konsentrasi ekstrak titik Kx.

\subsubsection{Pengujian pengaruh $p H$ terhadap aktivitas antibakteri ekstrak}

Masing-masing sebanyak 1 g ekstrak dilarutkan dengan $9 \mathrm{ml}$ aquades steril yang mengandung 10\% tween 20, yang telah diatur $\mathrm{pH}$ sesuai dengan perlakuan menggunakan 0,5 N NaOH atau 0,5 N HCl. Larutan ekstrak tersebut siap digunakan dalam pengujian.

Sejumlah 0,5 $\mathrm{ml}\left(10^{7} \mathrm{CFU} / \mathrm{ml}\right)$, disebarkan secara merata di permukaan NA di dalam cawan. Sumur dibuat dengan cara melubangi permukaan NA dengan tips diameter $6 \mathrm{~mm}$. Setiap sumur ditetesi dengan $60 \mu \mathrm{l}$ ekstrak 10\% (b/v) sesuai variasi tingkat keasamam $(\mathrm{pH})$ ekstrak $(4,5,6,7,8,5)$ Tiaptiap cawan dimasukkan ke dalam inkubator dengan suhu $37^{\circ} \mathrm{C}$ dengan waktu inkubasi 24 jam. Diameter penghambatan diukur menggunakan caliper (Balouiri et al., 2016).

\subsubsection{Pengujian stabilitas antibakteri ekstrak terhadap pemanasan suhu $100^{\circ} \mathrm{C}$}

Sejumlah 0,5 ml kultur bakteri uji $\left(10^{7} \mathrm{CFU} / \mathrm{ml}\right)$, disebarkan di permukaan NA di dalam cawan. Selanjutnya pada medium dibuat sumur berdiameter $6 \mathrm{~mm}$ dengan tips. Selanjutnya sejumlah $60 \mu \mathrm{l}$ ekstrak yang sudah mengalami perlakuan pemanasan suhu $100^{\circ} \mathrm{C}$ dengan waktu $0,5,10,15$, 
20, 25 menit dimasukkan ke dalam tiap-tiap sumur. Cawan kemudian diinkubasi dalam incubator suhu $37^{\circ} \mathrm{C}$ dalam waktu 24 jam. Diameter penghambatan diukur dengan menggunakan caliper (Balouiri et al., 2016).

\subsubsection{Pengujian pengaruh konsentrasi natrium klorida terhadap aktivitas antibakteri}

Sejumlah $0,5 \mathrm{ml}$ kultur bakteri uji sebanyak $10^{7}$ $\mathrm{CFU} / \mathrm{ml}$ disebarkan di permukaan NA di dalam cawan. Selanjutnya di permukaan NA dilubangi menggunakan tips berdiameter $6 \mathrm{~mm}$. Setiap sumur dimasukkan $60 \mu \mathrm{l}$ ekstrak heksan $10 \%$ yang mengandung sodium klorida sesuai dengan perlakuan, yaitu 0 (tanpa $\mathrm{NaCl}$ ), 1, 2, 3, 4 dan 5\% (b/v). Kemudian tiap-tiap cawan dimasukkan dalam incubator $37^{\circ} \mathrm{C}$ lalu diinkubasi selama waktu 24 jam. Diameter zona hambat di sekitar sumur diukur menggunakan caliper (Balouiri et al., 2016).

\section{Hasil dan Pembahasan}

\subsection{Pengaruh konsentrasi ekstrak terhadap aktivitas antibakteri}

Uji efek konsentrasi ekstrak heksan kulit batang akway terhadap aktivitas antibakteri dilakukan pada selang konsentrasi 0-25\%. Hasil uji menunjukkan bahwa ekstrak heksan kulit batang akway dapat menghambat pertumbuhan bakteri E. coli, B. cereus dan $S$. aureus masing-masing dengan selang penghambatan 9,77-12,27 $\mathrm{mm}, 14,40-16,60 \mathrm{~mm}$ dan 7,82-14,22 mm (Tabel 1).

Hasil analisis statistik menunjukkan bahwa aktivitas antibakteri ekstrak heksan kulit batang akway sangat bergantung pada konsentrasi ekstrak yang digunakan. Aktivitas penghambatan pertumbuhan bakteri cenderung meningkat seiring dengan meningkatnya konsentrasi ekstrak. Kecenderungan ini juga dilaporkan terhadap ekstrak heksan daun Napoleoneae imperalis pada konsentrasi 2,5-20\% (Anowi, Onyegbule, Gugu, \& Utoh-Nedosa , 2012), biji Swietenia humilis 0,010,1\% (Asmara, Hernawan, Nuzlia, \& Maryana , 2013) dan daun Ocimum gratissimum 3-10\% (Ekwenchi, Oluigbo, \& Akpuaka , 2014). Pola peningkatan penghambatan ini diduga disebabkan peningkatan konsentrasi ekstrak berdampak pada bertambahnya jumlah senyawa antibakteri yang berdifusi di dalam agar sehingga diameter zona penghambatan dalam medium agar semakin besar (Seow et al., 2014).

Tabel 1. juga menunjukkan bahwa bakteri $P$. aeruginosa resisten terhadap ekstrak heksan kulit batang akway dan penicillin G. Hal ini diduga disebabkan $P$. aeruginosa ATCC27853 merupakan bakteri yang resisten terhadap berbagai jenis antibiotik karena memiliki sistem pertahanan sel yang disebut multidrugs efflux pump yang berfungsi memompa senyawa antibakteri atau antibiotik ke luar sel (ARDB, 2009).

Tabel 1

Aktivitas Antibakteri Pada Beberapa Konsentrasi Ekstrak

\begin{tabular}{|c|c|c|c|c|}
\hline Konsentrasi & \multicolumn{4}{|c|}{ Diameter Zona Hambat Rataan (mm) } \\
\hline (\%) & E. coli & B. cereus & P. aeruginosa & S. aureus \\
\hline 0 & $6.00^{\mathrm{a}}$ & $6.00^{\mathrm{a}}$ & $6.00^{\mathrm{a}}$ & $6.00^{\mathrm{a}}$ \\
\hline 5 & $9.77^{b}$ & $14.40^{\mathrm{cd}}$ & $6.00^{\mathrm{a}}$ & $7.82^{\mathrm{a}}$ \\
\hline 10 & $10.42^{b}$ & $16.37^{\mathrm{cd}}$ & $6.00^{\mathrm{a}}$ & $12.70^{\mathrm{bc}}$ \\
\hline 15 & $10.52^{\mathrm{b}}$ & $15.47 \mathrm{~cd}$ & $6.00^{a}$ & $13.27^{\mathrm{cd}}$ \\
\hline 20 & $12.27^{b c}$ & $16.27 \mathrm{~cd}$ & $6.00^{a}$ & $14.22^{\mathrm{cd}}$ \\
\hline 25 & $11.75^{b}$ & $16.60^{d}$ & $6.00^{\mathrm{a}}$ & $13.27^{\mathrm{cd}}$ \\
\hline $\begin{array}{c}\text { Penicilin G } \\
(10 \%)\end{array}$ & 30.15 & 16.62 & 6.00 & 59.87 \\
\hline
\end{tabular}

Keterangan : angka yang diikuti dengan huruf yang sama

menunjukan perlakuan tidak berbeda nyata pada uji BNJ $\alpha-0.05$

\subsection{Konsentrasi hambat minimum (KHM)}

KHM adalah konsentrasi ekstrak terendah yang dapat menghambat pertumbuhan bakteri uji. Hasil pengujian menunjukkan bahwa KHM ekstrak heksan batang akway untuk bakteri $B$. cereus, E. coli, dan $S$. aureus masing-masing adalah 0,35\%, 0,51\% dan 0,89\% (Tabel 2). Hasil KHM ekstrak heksan kulit batang akway sebesar 0,35-0,89\% relatif lebih rendah dibandingkan dengan ekstrak heksan Napoleoneae imperalis dan Ocimum gratissimum yang masing-masing sebesar 2,5-20\% dan 2,5-10\% (Anowi et al., 2012; Ekwenchi et al., 2014). Hasil tersebut menunjukkan bahwa kapasitas antibakteri ekstrak heksan kulit batang akway lebih kuat dibandingkan dengan ekstrak heksan $N$. imperalis dan 0. gratissimum

Tabel 2

Konsentrasi Hambat Minimum (KHM)

\begin{tabular}{lccc}
\hline \multicolumn{1}{c}{ Bakteri } & Regresi Linear & $\mathbf{R}^{2}$ & KHM \\
\hline E. coli & $\mathrm{Y}=14.687 \mathrm{X}-10.655$ & 0.84 & $0.51 \%$ \\
B. cereus & $\mathrm{Y}=65.634 \mathrm{X}-22.377$ & 0.89 & $0.35 \%$ \\
S. aureus & $\mathrm{Y}=34.542 \mathrm{X}-44.394$ & 0.81 & $0.89 \%$ \\
\hline
\end{tabular}

Tabel 2. juga menunjukkan bahwa $B$. cereus merupakan bakteri yang paling rentan atau sensitif terhadap ekstrak heksan kulit batang akway, kemudian diikuti oleh $E$. coli sedangkan bakteri $S$. aureus merupakan bakteri yang paling tahan terhadap ekstrak kulit batang akway. Perbedaan sensitivas bakteri terhadap ekstrak heksan juga dilaporkan pada ekstrak Temnoplerus alexandri dan Eclipta alba. Uma dan Parvathavarthini (2010) melaporkan, bahwa $B$. subtilis merupakan bakteri yang paling sensitif terhadap ekstrak heksan Temnoplerus alexandri dengan KHM sebesar 0,0025 
$\mathrm{mg} / \mathrm{ml}$ selanjutnya diikuti $S$. aureus dan E. coli dengan KHM masing-masing sebesar $0,05 \mathrm{mg} / \mathrm{ml}$ dan $0,625 \mathrm{mg} / \mathrm{ml}$. Sebaliknya pada ekstrak heksan Eclipta alba dilaporkan $S$. aureus dan E. coli merupakan bakteri yang paling sensitif terhadap ekstrak dengan KHM $90 \mu \mathrm{g} / \mathrm{ml}$, sedangkan B. cereus merupakan bakteri yang paling tahan terhadap ekstrak dengan KHM $300 \mu \mathrm{g} / \mathrm{ml}$ (Pandey, Singh, Sharma, \& Lata, 2011). Perbedaan ketahanan bakteri terhadap ekstrak heksan kulit batang akway diduga masing-masing bakteri memiliki sensitivitas yang berbeda-beda terhadap senyawa antibakteri (Seow et al., 2014).

\subsection{Pengaruh level keasaman ( $p H)$ ekstrak}

Efek level keasaman ekstrak terhadap aktivitas antibakterinya dilakukan pada selang $\mathrm{pH}$ 4-8,5. Pengujian ditujukan untuk mengkaji pengaruh sinergis $\mathrm{pH}$ pada kapasitas antibakteri. Hasil penelitian menunjukkan bahwa terjadi peningkatan aktivitas antibakteri ekstrak sejalan dengan menurunnya $\mathrm{pH}$ ekstrak kulit batang akway pada kisaran $\mathrm{pH}$ 4-7. Aktivitas antibakteri ekstrak pada pH 7 terhadap bakteri B. cereus, E. coli, dan S. aureus secara berurutan adalah 16,65 mm, 12,25 mm, dan $14,66 \mathrm{~mm}$. Aktivitas antibakteri tersebut cenderung meningkat menjadi $14,98 \mathrm{~mm}, 18,80 \mathrm{~mm}$ dan 17,88 mm pada $\mathrm{pH} 4$ (Tabel 3). Hasil memperlihatkan bahwa level keasaman (pH) tidak memberikan pengaruh yang nyata pada aktivitas antibakteri.

Seperti yang terlihat dalam Tabel 3, perlakuan $\mathrm{pH}$ rendah bersifat meningkatkan aktivitas antibakteri ekstrak heksan kulit batang akway. Pola yang sama juga dilaporkan terjadi pada ekstrak bawang putih (Anees, Ravi, \& Ghorgare , 2015) dan ekstrak daun Carica papaya (Romasi, Karina, \& Parhusip , 2011). Efek sinergis $\mathrm{pH}$ rendah terhadap aktivitas antibakteri ekstrak kulit batang akway diduga pada konsentrasi $[\mathrm{H}+]$ yang tinggi $(\mathrm{pH}$ rendah), ion $\mathrm{H}+$ mampu berdifusi masuk melalui membran ke dalam sitoplasme sel bakteri. Ion $\mathrm{H}+$ yang melewati membran akan menginaktivasi enzim-enzim dalam membran dan mengganggu sistem transpor ion dan nutrien ke dalam sel (Rahman, 2007). Kerusakan membran sel dapat mempercepat proses difusi senyawa antibakteri berdifusi ke dalam sitoplasma lalu menghambat aktivitas di dalam sel.

Peningkatan aktivitas antibakteri ekstrak heksan kulit batang akway juga terjadi pada $\mathrm{pH}$ 8,5 dibandingkan dengan $\mathrm{pH}$ 7. Peningkatan aktivitas antibakteri pada $\mathrm{pH}$ alkalin $(\mathrm{pH} 8,5)$ disebabkan aktivitas $\mathrm{OH}^{-}$terhadap membrane sel bakteri. Menurut Aquiar, Guerreiro-Tanomaru, Faria, Leonardo, \& Tanomaru-Filho, (2015), ion hidroksil merupakan radikal bebas yang sangat reaktif yang bekerja pada komponen membran dan mempengaruhi aktivitas membrane sel. Ion $\mathrm{OH}^{-}$ menyebabkan denaturasi protein membran sehingga mengganggu transpor nutrien lewat membran, juga bersifat merusak lapisan fosfolipid membran melalui reaksi peroksidasi lipid (Mohammadi, Shalavi, \& Yazdizadeh, 2012). Kerusakan pada membran sel bakteri akan memudahkan senyawa antibakteri masuk ke dalam sitoplasma sel bakteri dan mengganggu proses metabolisme sel sehingga menyebabkan kematian sel bakteri.

Tabel 3

Aktivitas Antibakteri Ekstrak pada Beberapa Level Keasaman

\begin{tabular}{cccc}
\hline $\begin{array}{c}\text { Level } \\
\text { Keasaman } \\
\text { (pH) }\end{array}$ & \multicolumn{3}{c}{ Diameter Zona Hambat Rataan (mm) } \\
\cline { 2 - 4 } & E. coli & B. cereus & S. aureus \\
\hline 4 & $14.98^{\mathrm{b}}$ & $18.80^{\mathrm{d}}$ & $17.88^{\mathrm{cd}}$ \\
5 & $12.88^{\mathrm{a}}$ & $17.51^{\mathrm{cd}}$ & $17.06^{\mathrm{c}}$ \\
6 & $12.64^{\mathrm{a}}$ & $17.23^{\mathrm{c}}$ & $16.39^{\mathrm{bc}}$ \\
7 & $12.25^{\mathrm{a}}$ & $16.65^{\mathrm{c}}$ & $14.66^{\mathrm{b}}$ \\
8.5 & $12.56^{\mathrm{a}}$ & $17.56^{\mathrm{cd}}$ & $17.40^{\mathrm{cd}}$ \\
\hline
\end{tabular}

Keterangan : notasi huruf yang sama setelah angka menunjukan perlakuan tidak berpengaruh nyata dengan uji BNJ $\alpha-0.05$.

Peningkatan aktivitas antibakteri ekstrak heksan kulit batang akway dengan menurunnya $\mathrm{pH}$ mengindikasikan ekstrak heksan berpotensi digunakan sebagai pengawet pada pangan khususnya pangan dengan kandungan asam yang tinggi atau $\mathrm{pH}$ rendah.

\subsection{Pengaruh pemanasan terhadap aktivitas antibakteri ekstrak}

Pengujian efek perlakuan panas suhu $100^{\circ} \mathrm{C}$ pada waktu 0-25 menit terhadap ekstrak heksan kulit batang akway bertujuan mengevaluasi stabilitas senyawa antibakteri dalam ekstrak heksan kulit batang akway. Hasil pengujian memperlihatkan bahwa aktivitas antibakteri ekstrak heksan kulit batang akway pada bakteri B. cereus, E. coli, dan $S$. aureus masing-masing sebesar 17,18-17,68 mm, 11,50-12,00 mm, dan 14,50-16.00 mm (Tabel 4).

Tabel 4

Pengaruh Pemanasan Ekstrak terhadap Aktivitas Antibakteri

\begin{tabular}{cccc}
\hline $\begin{array}{c}\text { Pemanasan Pada } \\
\mathbf{1 0 0}^{\circ} \mathbf{C} \text { (menit) }\end{array}$ & \multicolumn{3}{c}{ Diameter Zona Hambat (mm) } \\
\cline { 2 - 4 } & E.coli & B. cereus & S. aureus \\
\hline 0 & $11.75^{\mathrm{a}}$ & $17.38^{\mathrm{a}}$ & $16.00^{\mathrm{a}}$ \\
5 & $11.50^{\mathrm{a}}$ & $17.68^{\mathrm{a}}$ & $16.28^{\mathrm{a}}$ \\
10 & $12.00^{\mathrm{a}}$ & $17.20^{\mathrm{a}}$ & $14.88^{\mathrm{a}}$ \\
15 & $11.50^{\mathrm{a}}$ & $17.18^{\mathrm{a}}$ & $14.58^{\mathrm{a}}$ \\
20 & $11.80^{\mathrm{a}}$ & $17.45^{\mathrm{a}}$ & $15.30^{\mathrm{a}}$ \\
25 & $11.30^{\mathrm{a}}$ & $17.35^{\mathrm{a}}$ & $14.50^{\mathrm{a}}$ \\
\hline
\end{tabular}


Analisis varian menunjukkan bahwa perlakuan pemanasan pada suhu $100^{\circ} \mathrm{C}$ dengan waktu pemanasan sampai 5 menit tidak memberikan pengaruh nyata pada karakteristik antibakteri ekstrak heksan kulit batang akway. Hasil yang serupa juga ditemukan pada ekstrak Panax ginseng dan daun Paveta indica. Senyawa antibakteri ekstrak P. ginseng tahan terhadap pemanasan suhu $100^{\circ} \mathrm{C}$ dalam waktu 60 menit (Na, Kim, Rhee, \& Oh, 2018), sedangkan komponen yang bersifat antibakteri dalam ekstrak daun Paveta indica stabil selama pemanasan selama 15 menit pada suhu $100^{\circ} \mathrm{C}$ (Gupta, Kaur, Simlai, \& Roy, 2013). Hasil memperlihatkan bahwa senyawa-senyawa antibakteri penyusun ekstrak kulit batang akway stabil pada pemanasan suhu $100^{\circ} \mathrm{C}$ dalam waktu 5 menit dan berpotensi digunakan sebagai pengawet makanan yang menggunakan perlakuan pemanasan $100^{\circ} \mathrm{C}$.

\subsection{Pengaruh konsentrasi garam}

Pengujian pengaruh konsentrasi natrium klorida ekstrak heksan kulit batang akway diterapkan pada selang konsentrasi $\mathrm{NaCl} 0-5 \%$. Perlakuan ini bertujuan untuk mengevaluasi pengaruh sodium klorida pada aktivitas antibakteri ekstrak. Data hasil pengujian memperlihatkan bahwa aktivitas antibakteri ekstrak pada beberapa level konsentrasi natrium klorida terhadap bakteri $B$. cereus, E. coli, dan $S$. aureus masing-masing sebesar 16,98-17,63 $\mathrm{mm}, 12,65-13,34 \mathrm{~mm}$, dan 16,24-17,00 mm (Tabel 5).

Tabel 5

Karakteristik Antibakteri Ekstrak pada Variasi Konsentrasi Natrium Klorida

\begin{tabular}{cccc}
\hline \multirow{2}{*}{$\begin{array}{c}\text { Konsentrasi } \\
\text { NaCl (\%) }\end{array}$} & \multicolumn{3}{c}{ Diameter Zona Hambat Rataan (mm) } \\
\cline { 2 - 4 } & E. coli & B. cereus & S. aureus \\
\hline 0 & $12.65^{\mathrm{a}}$ & $17.63^{\mathrm{a}}$ & $17.00^{\mathrm{a}}$ \\
1 & $13.09^{\mathrm{a}}$ & $17.05^{\mathrm{a}}$ & $16.46^{\mathrm{a}}$ \\
2 & $13.11^{\mathrm{a}}$ & $17.05^{\mathrm{a}}$ & $16.48^{\mathrm{a}}$ \\
3 & $13.19^{\mathrm{a}}$ & $17.35^{\mathrm{a}}$ & $16.53^{\mathrm{a}}$ \\
4 & $13.06^{\mathrm{a}}$ & $16.98^{\mathrm{a}}$ & $16.53^{\mathrm{a}}$ \\
5 & $13.34^{\mathrm{a}}$ & $17.24^{\mathrm{a}}$ & $16.24^{\mathrm{a}}$ \\
\hline
\end{tabular}

Analisis varians menunjukkan bahwa level konsentrasi natrium klorida ekstrak tidak memberikan pengaruh nyata pada karakteristik antibakteri ekstrak heksan kulit batang akway. Hasil analisis tersebut menjelaskan bahwa natrium klorida sampai dengan konsentrasi 5\% tidak bersifat sinergis atau mereduksi kapasitas antibakteri ekstrak.

Konsentrasi natrium klorida sebesar 5\% tidak berdampak sinergis aktivitas antibakteri ekstrak diduga level konsentrasi tersebut tidak berpengaruh terhadap komponen antibakteri dalam ekstrak dan pertumbuhan bakteri uji dalam medium agar. Konsentrasi garam 5\% tidak berpengaruh terhadap pertumbuhan bakteri diduga bakteri masih dapat mentoleransi konsentrasi garam tersebut. Tsai et al. (2011), melaporkan bahwa bakteri $S$. aureus dapat mentoleransi kandungan garam sodium klorida 5\% pada lingkungan tumbuhnya, sedangkan B. cereus dan E. coli, masih bisa bertumbuh pada lingkungan tumbuh dengan kadar sodium klorida mencapai 5\% (Patra \& Baek, 2016; Hrenovic \& Ivankovic, 2009).

\section{Kesimpulan}

Ekstrak heksan kulit batang akway memiliki karakteristik menghambat pertumbuhan bakteri $B$. cereus, E. coli, dan $S$. aureus dengan konsentrasi hambat minimum $0,35-0,89 \%$ sedangkan bakteri $P$. aeruginosa resisten terhadap ekstrak. Perlakuan pemanasan suhu $100^{\circ} \mathrm{C}$ dalam waktu 5 menit juga penambahan natrium klorida $\leq 5 \%$ tidak mereduksi aktivitas antibakteri ekstrak. Penurunan $\mathrm{pH} 7$ menjadi pH 4 dan peningkatan $\mathrm{pH} 7$ menjadi $\mathrm{pH} 8$ bersifat meningkatkan aktivitas antibakteri ekstrak heksan kulit batang akway. Ekstrak heksan kulit batang akway berpotensi sebagai pengawet pangan khususnya untuk pangan dengan perlakuan panas pada $100^{\circ} \mathrm{C}$ dan pangan $\mathrm{pH}$ rendah. Ekstrak ini berpotensi sebagai pengawet pangan yang diproses dengan pemanasan dan pengasaman.

\section{Ucapan Terima Kasih}

Ucapan terima kasih disampaikan kepada Kepala Laboratorium Teknologi Pertanian, Fakultas Teknologi Pertanian atas bantuan berupa penggunaan fasilitas laboratorium untuk pelaksanaan penelitian ini dan kepada Kementerian Ristek dan Dikti sebagai penyandang dana.

\section{Daftar Pustaka}

Anees, A. M., Ravi, S., \& Ghorgare, P. (2015). Studies on antimicrobial activity of spices and effect of temperature and $\mathrm{pH}$ on its antimicrobial properties. IOSR Journal of Pharmacy and Biological Sciences, 10(1), 99-102.

Anowi, C. F., Onyegbule, A. F., Gugu, T. H., \& UtohNedosa, U. A. (2012). Evaluation of antimicrobial properties of $n$-hexane extract of the leaves of Napoleoneae imperalis family Lecythiaceae. IJPSR, 3(7), 2154-2158

ARDB. (2009). Antibiotic resistance data base: Pseudomonas aeruginosa. Center for Bioinformatic and Computational: Biology University of Maryland College Park MD20742.

Aquiar, A. S., Guerreiro-Tanomaru, J. M., Faria, G., 
Leonardo, R. T., \& Tanomaru-Filho, M. (2015). Antimicrobial activity and $\mathrm{pH}$ of calcium hydroxide and zinc oxide nanoparticles intracanal medication and association with chlorhexidine. Journal of Contemporary Dental Practice, 16(8), 624-629.

Asmara, A. P., Hernawan, Nuzlia, C., \& Maryana, R. (2018). Antibacterial bioactivity of $n$-hexane extract from mahogany (Swietenia humilis Zucc.) seed and its fatty acid compound identification. The 2nd International Conference on Natural Products and Bioresource Sciences 1-2 Nov. 2018. Tangerang, Indonesia.

Balouiri, M., Sadiki, M., \& Ibnsouda, S. K. (2016). Methods for in vitro evaluating antimicrobial activity : A review. J. Pharma Anal. 6(2), 7179.

Bloomfield, S. (1991). Methods for assesing antimicrobial activity. In S. P. Denyer, H. B. Hugo, editor. Mechanism of action of chemical biocides their study and exploitation (pp.1-22). London: Scientific Publication.

Campelo, M. C. S., Medeiros, J. M.S. \& Silva, J. B. A. Natural products in food preservation. International Food Research Journal, 26(1), 41 $-46$.

Cepeda, G. N., Santoso, B. B., Lisangan, M. M., \& Silamba, I. (2010). Penapisan fitokimia akway. Jurnal Agrotek, 1(8), 28-33.

Cepeda, G. N., Santoso, B. B., Lisangan, M. M., \& Silamba, I. (2011a). Komposisi kimia minyak atsiri kulit batang akway (Drimys piperita Hook f.). Bionatura, 13(2), 118-124.

Cepeda, G. N., Santoso, B. B., Lisangan, M. M., \& Silamba, I. (2011b) Komposisi kimia minyak atsiri daun akway. Makara Sains, 15(1), 63-66.

Cepeda, G. N., Lisangan, M. M., \& Roreng, M. K. (2018). Aktivitas penangkalan radikal bebas dan kemampuan reduksi ekstrak kulit batang akway (Drimys piperita Hook f.). Jurnal Aplikasi Teknologi pangan, 7(4),168-173.

Cushnie, T. P. T., \& Lamb, A. J. (2005). Antimicrobial activity of flavonoids. Int J Antimicrob Agents, 26(5), 343-356

Da Silva, A. C., Lopes, P. M., De Azevedo, M. M., Costa, D. C., Alviano, C. S., \& Alviano, D. S. (2012). Biological activities of $\alpha$-pinene and $\beta$-pinene enantiomer. Molecules, 17, 6305-6316.

Ekwenchi, M. M., Oluigbo, J., \& Akpuaka, A. (2014). Antibacterial activity of n-hexane extract of Ocimum gratissimum leaves. IOSR Journal Applied Chemistry, 7(5), 6-10.

Gupta, V. K., Kaur, C., Simlai, A., \& Roy, A. (2013). Antimicrobial activity of Pavetta indica leaves. Journal of Applied Pharmaceutical Science, 3(4), 078-082.

Hrenovic, J., \& Ivankovic, T. (2009). Survival of and

Escherichia coli and Acinetobacter junii at various concentrations of sodium chloride. EurAsia J BioSci, 3(1), 144-151.

Krishnan, K. R., Babuskin, S., Babu, P. A. S., Sasikala, M., Sabina, K., Archana, G., et al. (2014). Antimicrobial and antioxidant effects of spice extracts on the shelf life extension of raw chicken meat. International Journal of Food Microbiology, 171, 32-40.

Mahmud, J., \& Khan, R. A. (2018). Characterization of natural antimicrobials in food system. Advances in Microbiology, 8, 894-916

Mohammadi, Z., Shalavi, S., \& Yazdizadeh, M. (2012). Antimicrobial activity of calcium hydroxide in endodontics: A Review. Chonnam Medical Journal, 48,133-140

Mostafa, A. A., Al-Askar, A. A., Almaary, K. S., Dawoud, T. M., Sholkamy, E. N., \& Bakri, M. M. (2018). Antimicrobial activity of some plant extracts against bacterial strains causing food poisoning diseases. Saudi Journal of Biological Sciences, 25, 361-366.

Na, S., Kim, J. H., Rhee, Y. K., \& Oh, S. W. (2018). Enhancing the antimicrobial activity of ginseng against Bacillus cereus and Staphylococcus aureus by heat treatment. Food Sci Biotechnol. 27(1), 203-210.

Pandey, M. K., Singh, G. N., Sharma, R. K., \& Lata, S. (2011). Antibacterial activity of Eclipta alba (L.) Hassk. Journal of Applied Pharmaceutical Science, 1(7),104-107.

Patra, J. K., \& Baek, K. H. (2016). Antibacterial activity and action mechanism of the essential oil from Enteromorpha linza L. against foodborne patogenic bacteria. Molecules, 21(3), 388.

Rahman, M. S. (2007). pH in Food Preservation. In M. S. Rahman, Handbook of Food Preservation 2nd edition (pp. 287-298). Boca Raton: CRC Press.

Romasi, E. F., Karina, J., \& Parhusip, A. J. N. (2011). Antibacterial activity of papaya leaf extracts against patogenic bacteria. Makara Seri Teknologi, 15(2), 173-177.

Seow, Y. X., Yeo, C. R., Chung, H. L., \& Yuk, H. G. (2014). Plant essential oils as active antimicrobial agents. Crit Rev Food Sci Nutr. 54(5): 625-644.

Stevens, $\quad P$

F.

(2017). http://www.mobot.org/MOBOT/research/AP web/July 4, 2017. Retrieved Maret 2, 2019, from Canellales. Angiosperm Phylogeny Website: http://www.mobot.org

Syakir, M., Bermawie, N., Agusta, H., \& Paysei, E. N. (2011). Karakterisasi sifat morfologi dan penyebaran batang akway (Drimys sp) di Papua Barat. Jurnal Penelitian Tanaman Industri, 17(4), 169-173 
Tommasen, J. (2010). Assembly of outer-membrane proteins in bacteria and mitochondria. Microbiol. 156(9), 2587-2596.

Tsai, M., Ohniwa, R. L., Kato, Y., Takeshita, S. L., Ohta, T., Saito, S., et al. (2011). Staphylococcus requires cardiolipin for survival under condition of high salinity. BMC Microbiol, 11(13), 1-12.

Uma, B. \& Parvathavarthini, R. (2010). Antibacterial Effect of Hexane Extract of Sea Urchin, Temnopleurus alexandri (Bell,1884). International Journal of PharmTech Research, 2(3), 1677-1680.

Wang, W., Li, N., Luo, M., Zu, Y., \& Efferth, T. (2012). Antibacterial activity and anticancer activity of Rosmarinus officinalis L. essential oil compared to that of its main components. Molecules, 17(3), 2704-2713. 